\title{
Elintarvikkeiden kulutustrendit ja ennusteet vuoteen 2005
}

\author{
Sanna Rusanen ja Jukka Kola \\ Taloustieteen laitos, PL 2700014 Helsingin yliopisto, sanna.rusanen@helsinki.fi
}

\begin{abstract}
Johdanto
Elintarvikkeiden kulutus on muuttunut 1900-luvulla oleellisesti. Kulutuskehitystä ovat ohjanneet mm. hintojen ja hintasuhteiden muutokset, kansantalouden nousu- ja laskukaudet, kuluttajien preferenssien muuttuminen, tuotekehittely ja terveysvalistus. Useiden hyödykkeiden kulutuksessa on myös havaittavissa selkeää trendinomaista kehitystä. Ruokavalio on lisäksi monipuolistunut, keventynyt ja perinteinen käsitys kulutuksesta ja siihen vaikuttavista tekijöistä on muuttunut. Kulutuksen tunteminen on tärkeää mm. maatalouspolitiikan suunnittelussa ja toteutuksessa ja sen merkitys on korostunut: kesällä 2003 uudistettu EU:n yhteinen maatalouspolitiikka CAP suuntautuu selvemmin kohti kuluttajia.

Tutkimuksen tarkoituksena on ennakoida mihin suuntaan hyödykkeiden kulutus muuttuu vuosien 2002-2005 aikana. Seuraako kulutus viimevuotisia trendejä, ja kuinka suuria muutoksia on odotettavissa. Tutkimuksessa on mukana 11 hyödykettä: naudanliha, sianliha, siipikarjanliha, nestemäinen maito, jogurtti, viili, juusto, voi, margariini, peruna ja vihannekset.

Tutkimuksen tavoitteet ovat seuraavat:

- Kuvata pitkän aikavälin kulutustrendejä ravintotaseiden pohjalta

- Verrata Suomen ja Euroopan unionin elintarvikkeiden kulutuskehitystä toisiinsa 1990-luvulla

- Muodostaa kullekin elintarvikkeelle kysyntämalleja

- Estimoida kysynnän hinta-, tulo-ja ristijoustot

- Laatia kulutusennusteita vuoteen 2005
\end{abstract}

Tutkimuksen teoreettinen viitekehys perustuu kuluttajateoriaan, jonka mukaan taloustieteellisessä analyysissä tärkein kysyntää määräävä tekijä on hyödykkeen oma hinta. Kysyntään vaikuttavat myös muiden tuotteiden hinnat ja hintamuutokset sekä tulot. (Varian 1999.) Taloudellisten tekijöiden lisäksi kulutukseen vaikuttaa myös monet ei-taloudelliset tekijät, kuten preferenssit. Antonides ja van Raaij (1998, s. 23) tuovat esille myös demografiset tekijät, kuten iän, sukupuolen, koulutuksen, perheen koon, sosiaaliluokan ja muutokset näissä tekijöissä. Laurila (1994, s. 338) mainitsee myös terveysnäkemykset kulutusta ohjaavana tekijänä. Kiviniemi (2000, s. 17) toteaa myös eettisten ja eläinten hoitoon liittyvien tekijöiden vaikuttavan yhä enenevissä määrin kuluttajien ostopäätöksiin.

\begin{abstract}
Aineisto ja menetelmät
Tutkimusta varten jokaisesta hyödykkeestä muodostettiin vuosittainen kulutusaikasarja henkeä kohden. Aineisto kerättiin ravintotaseista 30 vuoden ajalta vuodesta 1970 vuoteen 2001. Kuluttajahinnat kerättiiin vuosittaisista (Tilastokeskus 2001 ja 1996) ja neljännesvuosittaisista tai kuukausittaisista tilastoista, joista laskettiin vuoden keskihinta. Kustakin hyödykeryhmästä valittiin joko yksi tai useampi edustava hyödyke, joiden kuluttajahintoja painottamalla muodostettiin tutkimuksessa estimoitavan hyödykkeen hinta. Painotus perustui kuluttajahintaindeksin laadinnassa käytettyihin hyödykkeittäisiin kulutusosuuksiin. Tulomuuttujaksi valittiin kansantalouden tilinpidon yksityiset kulutusmenot. Nimelliset suureet deflatoitiin reaaliseksi elinkustannushintaindeksillä, siten että reaaliset arvot on sidottu vuoden 1990 rahanarvoon.

Tutkimusmenetelmänä oli ekonometrinen estimointi. Ekonometrisen tutkimuksen peruselementit ovat talousteoria ja historiallinen data. Kun teoria ja data yhdistetään sekä hyödynnetään tilastotieteen analyysimenetelmiä, päädytään ekonometriseen malliin. (Intriligator 1978, s. 2-4.) Tutkimuksessa peruslähtökohtana on lineaarinen yhden yhtälön regressiomalli, jossa selitettävää muuttujaa eli kysyntää pyritään selittämään riippumattomien eli selittävien muuttujien avulla. Selittäviksi tekijöiksi valittiin hinta-, tulo- ja dummymuuttujia sekä viivästeiset hinta- ja kulutusluvut. Hinta- ja tulomuuttujan mukanaolo perustuu kuluttajateoriaan ja muiden muuttujien tarkoituksena on vähentää mallin selittämätöntä vaihtelua. Tutkimuksessa käytettävien dummymuuttujien avulla pyritään saamaan esille EU:iin liittymisen, BSEkriisin sekä 1990-luvun alun laman merkitystä kulutukseen. Kulutuksessa esiintyvät trendit pyritään ottamaan huomioon trendimuuttujan avulla. Tutkimuksessa kullekin hyödykkeelle estimoitiin pienimmän neliösumman menetelmällä useita staattisia ja dynaamisia log-lineaarisia kysyntämalleja, joiden joukosta valittiin tilastollisten testien avulla paras mallispesifikaatio. Kriteereinä olivat selitysaste $\left(R^{2}\right)$, vapausas-
\end{abstract}


teilla tarkistettu selitysaste $\left(\bar{R}^{2}\right)$, F-testi, t-testi, p-arvo, korrelaatiokerroin, toleranssi ja Durbin-Watson testi.

Tutkimuksessa käytettävä staattinen malli on perusmuodoltaan seuraavanlainen:

$\ln q_{i}=\alpha_{i}+\mathrm{E}_{i} \ln x+\sum_{j \in J} e_{\mathrm{ij}} \ln p_{j}$

missä: $q_{i}$ on hyödykkeen $i$ kulutettu määrä, $\mathrm{kg} / \mathrm{hlö}$

$\alpha_{i}$ on yhtälön vakiotermi

$\mathrm{E}_{i}$ on hyödykkeen $i$ menojousto

$x$ on reaaliset kulutusmenot, eur/hlö

$e_{i j}$ on ristijousto eli hyödykkeen $i$ hintajousto hyödykkeen $j$ hinnan suhteen

$p_{j}$ on hyödykkeen $j$ reaalinen kuluttajahinta, eur $/ \mathrm{kg}$

Staattisuudella tarkoitetaan kysynnän välitöntä reagointia hinnan tai tulojen muutokseen kaikkien muiden tekijöiden pysyessä vakioina. Dynaamisuus ottaa huomioon myös aikajänteen (Tomek ja Robinson 1990, s. 16.) Dynaaminen malli poikeaa staattisesta mallista siten, että selitettävä muuttuja viivästetään ja lisätään selittäväksi muuttujaksi. Myös hintamuuttujaa voidaan viivästää, jolloin mitataan kuluttajan myöhäistä reagointia hinnanmuutokseen.

\section{Tulokset ja tulosten tarkastelu \\ Parhaat kysyntämalit}

Jokaisen hyödykkeen parhaaseen kysyntämalliin kuului hyödykkeen oma hinta, sen sijaan menomuuttuja oli mukana ainoastaan siipikarjanlihan, jogurtin ja juuston kysyntämallissa. Lamalla näyttäisi olleen vaikutusta sian-ja naudanlihan kulutukseen. BSE-kriisi selittänee osaltaan naudanlihan vuoden 2001 huomattavaa kulutuksen laskua. Siipikarjanlihan, maidon, juuston ja voin kulutuksissa on havaittavissa pitkällä aikavälillä trendinomaista kehitystä, jota vahvisti trendimuuttajan merkitsevyys kyseisissä malleissa. Tulosten mukaan EU:iin liittyminen vaikutti ainoastaan vihannesten kulutukseen ja vaikutus oli negatiivinen. Viivästetty kulutusmäärä osoittautui merkittäväksi selittäväksi tekijäksi sianlihan, viilin ja margariinin kysyntämalleissa. Tämä tarkoittaa, että aikaisemmalla kulutuksella on merkitystä kulutuspäätökseen.

\section{Kysynnän joustot}

Elintarvikkeiden kulutuksen on todettu olevan melko joustamatonta hinnan suhteen, mitä näkemystä tukevat myös tämän tutkimuksen tulokset. Alhaiset jouston arvot ovat elintarvikkeille ja yleisestikin välttämättömyyshyödykkeille tyypillisiä (taulukko 1). Merkillepantavaa oli, että voin ja jogurtin hintajoustot olivat lähellä ykköstä ja vihannesten hintajousto oli yksikköjoustavaa. Viili oli ainoa hyödyke, jonka hintajousto sai ykköstä suuremman arvon. Menojoustot olivat hintajoustojen tapaan melko alhaisia. Myös substituuttisuhteita saatiin esille. Siipikarjanliha ja sianliha osoittautuivat naudanlihaa korvaaviksi tuotteiksi. Sianlihan kulukseen puolestaan näyttäisi vaikuttavan naudanlihan hintakehitys. Viilin substituuttituotteeksi osoittautui jogurtti ja margariinin subsituutiksi voi. Lisäksi riisin ja vihannesten hinnoilla todettiin olevan vaikutusta perunan kulutukseen sekä perunan hinnalla puolestaan vihannesten kulutukseen.

Taulukko 1. Estimoidut hinta-, meno- ja ristijoustot.

\begin{tabular}{llll}
\hline \hline & Hintajousto & Menojousto & Ristijousto \\
\hline \hline Naudanliha & $-0,6$ & & 0,1 (siipikarja), 0,7 (sika) \\
Sianliha & $-0,4$ & 0,4 & 0,3 (nauta) \\
Siipikarjanliha & $-0,1$ & & \\
Nestemäinen maito & $-0,2$ & 0,8 & \\
Jogurtti & $-0,9$ & & 0,3 (jogurtti) \\
Viili & $-1,2$ & 0,6 & \\
Juusto & $-0,3$ & & 0,5 (margariini) \\
Voi & $-0,8$ & & 0,2 (riisi), 0,3 (vihannes) \\
Margariini & $-0,1$ & & 0,1 (peruna) \\
Peruna & $-0,1$ & & \\
Vihannekset & $-1,0$ & & \\
\hline
\end{tabular}


Verrattaessa joustojen arvoja aikaisempiin tutkimuksiin voidaan huomata selkeitä yhdenmukaisuuksia, mutta myös huomattavia eroja. Erot voivat johtua useista eri tekijöistä, kuten tutkimusajankohdasta, tutkimusjakson pituudesta, käytetyn datan ja estimointimenetelmän erilaisuudesta. Vertailua vaikeuttaa myös hyödykeryhmien erilaisuus ja koostumus. Joustojen arvot vaihtelevat oletettavasti myös sen mukaan perustuuko aikasarja-aineistotyyppinen data ravintotaseisiin vai kulutusbudjettidataan. Lisäksi joustojen suuruuteen vaikuttanee myös käytetäänkö suhteellisia vai fyysisiä suureita. (Laurila 1994, s. 389-390.)

\section{Kulutusennusteet vuosille 2002-2005}

Elintarvikkeiden kulutusennusteiden mukaan naudanlihan kulutus toipuu BSE-kriisistä ja kulutus kääntyy selkeään nousuun, joten vuoden 2001 naudanlihan kulutuksen notkahdus oli väliaikaista (taulukko 2). Sianlihan kulutus sen sijaan säilyy nykyisellä tasollaan. Siipikarjanlihan kulutuksen trendinomainen kasvu jatkuu edelleen yhtä nopeana kuin tähänkin asti.

Nestemäisen maidon kulutuksen trendinomainen lasku tulee jatkumaan myös lähitulevaisuudessa ja odotettavissa on jopa laskutrendin kiihtymistä Jogurtin vuoden 2001 kulutuksen heikkeneminen näyttää ennusteiden mukaan olleen väliaikaista ja kulutus olisi kääntynyt nousuun jo vuoden 2002 aikana, jonka jälkeen kulutus jälleen tasaantuu. Sen sijaan viilin kulutus tulee vähenemään entisestään. Muutamia vuosia tasaisena jatkunut juuston kulutus näyttää kääntyvän jälleen nousuun.

Voin kulutuksen laskutrendi jatkuu ennusteiden mukaan. Margariinin kulutus sen sijaan kääntyy lievään kasvuun. Perunan kulutus laski vuodesta 2001 vuoteen 2002, jonka jälkeen kulutuksen voidaan odottaa jälleen kasvavan. Vihannesten kulutuksessa on odotettavissa hienoista laskua.

Taulukko 2. Elintarvikkeiden kulutus vuosina 1999-2001 sekä tutkimuksen ennuste vuoteen 2005.

\begin{tabular}{lrrrrrrr}
\hline \hline kg/hlö/vuosi & 1999 & 2000 & 2001 & 2002 & 2003 & 2004 & 2005 \\
\hline \hline Naudanliha & 18,8 & 19,0 & 17,8 & 19,7 & 19,8 & 19,9 & 20,0 \\
Sianliha & 34,3 & 33,0 & 32,3 & 32,3 & 32,3 & 32,3 & 32,2 \\
Siipikarjanliha & 12,6 & 13,3 & 14,5 & 15,4 & 16,4 & 17,4 & 18,6 \\
Nestemäinen maito & 149,4 & 148,2 & 146,7 & 141,7 & 137,2 & 133,0 & 129,0 \\
Jogurtti & 17,2 & 17,2 & 17,0 & 17,3 & 17,4 & 17,4 & 17,3 \\
Viili & 6,2 & 6,0 & 6,0 & 6,0 & 5,8 & 5,6 & 5,5 \\
Juusto & 16,6 & 16,5 & 16,5 & 17,0 & 17,6 & 18,1 & 18,6 \\
Voi & 3,9 & 3,8 & 3,5 & 3,3 & 3,0 & 2,8 & 2,6 \\
Margariini & 8,1 & 7,7 & 7,8 & 8,1 & 8,3 & 8,3 & 8,3 \\
Peruna & 61,6 & 61,6 & 61,7 & 61,3 & 62,0 & 62,7 & 63,3 \\
Vihannekset & 64,2 & 64,6 & 63,1 & 61,9 & 60,8 & 59,8 & 58,7 \\
\hline
\end{tabular}

\section{Johtopäätökset}

Teorian mukaan taloustieteellisessä analyysissä tärkein kysyntää määräävä tekijä on hyödykkeen oma hinta. Tulokset kuitenkin osoittivat, ettei hinta ole pitkällä aikavälillä tärkein ostopäätöskriteeri: vaikka hintamuuttuja oli mukana kaikissa malleissa, omalle hinnalle saatu kerroin ei aivan yltänyt viiden prosentin merkitsevyystasolle, eikä hintamuuttuja yksistään selittänyt hyödykkeen kulutusta kovinkaan paljon. Myöskään tulot eivät osoittautuneet merkittäväksi kysyntää selittäväksi tekijäksi, mikä vahvistaa entisestään oletusta, että elintarvikkeiden kulutukseen vaikuttavat voimakkaasti muut kuin taloudelliset tekijät.

Saatuja ennusteita verrattiin Gallup Elintarviketiedon (2002) laatimiin ennusteisiin (taulukko 3). Gallupin ennusteet perustuvat taselaskelmien jäännöseriin. Juuston kulutusennusteet ovat samansuuntaisia, tosin juuston lähtötaso eroaa näiden kahden tutkimuksen välillä: Gallupin juuston kulutuslukuun sisältyy myös rahkan kulutus. Molemmat ennustavat voin kulutuksen laskevan, mutta tämän tutkimuksen mukaan laskutrendi on voimakkaampi. Margariinin ja sianlihan kulutusennusteet lähtevät eri suuntiin. Naudanlihan kulutuksen kasvu on tämän tutkimuksen mukaan selvästi Gallupin ennustetta suurempi. Siipikarjanlihan käyttö kasvaa molempien tutkimusten mukaan nopeaan tahtiin. 
Taulukko 3 . Gallup Elintarviketiedon "1" ja tämän tutkimuksen ennusteiden vertailu "2".

\begin{tabular}{|c|c|c|c|c|c|c|c|c|c|c|c|c|}
\hline \multirow[t]{2}{*}{ kg/hlö } & \multicolumn{2}{|c|}{ Juusto } & \multicolumn{2}{|c|}{ Voi } & \multicolumn{2}{|c|}{ Margariini } & \multicolumn{2}{|c|}{ Naudanliha } & \multicolumn{2}{|c|}{ Sianliha } & \multicolumn{2}{|c|}{ Siipikarjanliha } \\
\hline & 1 & 2 & 1 & 2 & 1 & 2 & 1 & 2 & 1 & 2 & 1 & 2 \\
\hline $\begin{array}{l}2003 \\
2005\end{array}$ & $\begin{array}{l}17,6 \\
18,6\end{array}$ & $\begin{array}{l}18,3 \\
18,8\end{array}$ & $\begin{array}{c}3 \\
2,6\end{array}$ & $\begin{array}{l}3,4 \\
3,4\end{array}$ & $\begin{array}{l}8,3 \\
8,3\end{array}$ & $\begin{array}{l}7,5 \\
7,3\end{array}$ & $\begin{array}{c}19,8 \\
20\end{array}$ & $\begin{array}{l}18,2 \\
18,2\end{array}$ & $\begin{array}{l}32,3 \\
32,2\end{array}$ & $\begin{array}{l}33,4 \\
34,4\end{array}$ & $\begin{array}{l}16,4 \\
18,6\end{array}$ & $\begin{array}{l}16,7 \\
18,3\end{array}$ \\
\hline
\end{tabular}

Maa- ja metsätalousministeriön tietopalvelukeskus (TIKE 2003) on julkaissut ennakkotiedot vuoden 2002 kulutuksesta, joka oli tutkimuksen ensimmäinen ennustevuosi. Vertaamalla tutkimuksen ennusteita vuodelle 2002 Tiken ennakkotietoihin, näyttäisi, että parhaat mallit saatiin siipikarjanlihan ja viilin kulutuksille (taulukko 4). Melko toimivat mallit saatiin myös sianlihan, jogurtin, juuston, perunan ja voin kulutuksen estimoimiseen. Suurimmat poikkeamat ennakkotietoihin verrattuna ovat naudanlihan, margariinin, vihannesten ja nestemäisen maidon kulutuksissa.

Taulukko 4. Vuoden 2001 kulutus sekä tutkimuksen ennusteet ja TIKEn ennakkotiedot vuodelle 2002.

\begin{tabular}{lrrr}
\hline \hline kg/hlö & Vuosi 2001 & Ennuste 2002 & TIKE ennakko 2002 \\
\hline \hline Naudanliha & 17,8 & 19,7 & 17,8 \\
Sianliha & 32,3 & 32,3 & 31,9 \\
Siipikarjanliha & 14,5 & 15,4 & 15,4 \\
Nestemäinen maito & 146,7 & 141,7 & 145,6 \\
Jogurtti & 17,0 & 17,3 & 17,0 \\
Viili & 6,1 & 6,0 & 6,0 \\
Juusto & 16,5 & 17,0 & 16,6 \\
Voi & 3,5 & 3,3 & 3,0 \\
Margariini & 7,9 & 8,1 & 7,6 \\
Peruna & 61,7 & 61,3 & 61,7 \\
Vihannekset & 63,1 & 61,9 & 65,2 \\
\hline
\end{tabular}

Kuluttajien vaatimukset elintarvikkeille ovat muuttuneet merkittävästi. Hinta ei ole usein ratkaisevin ostopäätöskriteeri kaikille kuluttajaryhmille. Luonnollisesti taloudellisilla tekijöillä on edelleen merkitystä, mutta kuluttajat preferoivat hyödykkeitä yhä useampien ja kuluttajasegmenteittäin ja väestöryhmittäin vaihtelevien kriteerien perusteella. Oletettavasti valintoihin vaikuttavat yhä enemmän mm. yhteiskunnassa vallitsevat arvostukset, ruokaan liittyvä informaatio, valmistaja, tuotantoon liittyvät tekijät, eettisyys ja terveellisyys. Tämä merkitsee sitä, että elintarvikkeiden kulutusmuutosten ennakoiminen ja luotettavien kulutusennusteiden tekeminen on aikaisempaa haastavampaa. Olisikin hyödyllistä selvittää, miten nämä kulutukseen vaikuttavat ei-taloudelliset tekijät voitaisiin kvantifioida ja ottaa huomioon kulutusennusteita tehtäessä, tai miten kvalitatiivisin menetelmin saatuja tuloksia kuluttajan valinnoista voitaisiin hyödyntää kvantitatiivisessa analyysissa. Kulutusta olisi myös tarpeellista tutkia eri kuluttajasegmenttien kautta.

\section{Kirjallisuus}

Antonides, G. \& van Raaij, W. F. 1998. Consumer Behaviour. A European Perspective. 619 p. UK. Intriligator, M. D. 1978. Econometric Models, Techniques and Applications. 638 p. New Jersey.

Kiviniemi, J. 2000. Broilerin kysyntä ja tarjontaketjun ohjaus Suomessa. Helsingin yliopisto. Taloustieteen laitos. Pro gradu -tutkielma. 73 s. Helsinki.

Laurila, I. P. 1994. Demand for Food Products in Finland: A Demand SystemApproach. Agricultural Science in Finland. 3: 315-420 p. Helsinki.

Suomen Gallup Elintarviketieto. 2002. Maataloustuotanto vuonna 2001 ja skenaario vuoteen 2008. Espoo. TIKE 2003. Maa- ja metsätalousministeriön tietopalvelukeskus. Ravintotase 2001 ja 2002 ennakko. Helsinki.

Tilastokeskus. 1996. Kuluttajahintatilasto 1996 ja sitä aikaisemmat julkaisut. Helsinki.

Tilastokeskus. 2001. Hinta- ja palkkatiedote 2001 ja sitä aikaisemmat julkaisut.Helsinki.

Tomek, W. G. \& Robinson, K. L. 1990. Agricultural Product Prices. 3. painos. 360 p. Ithaca.

Varian, H. R. 1999. Intermediate Microeconomics. A Modern approach. $5^{\text {th }}$ edition. 662 p. New York. 